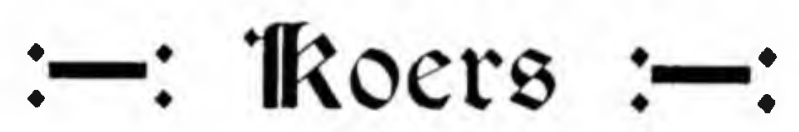

TWEEMAANDELIKSE TYDSKRIF

$\begin{array}{lll}\text { Jaargang XXV DESEMBER } 1957 & \text { No. } 3\end{array}$

\title{
Rasseverhoudinge in die Skrif
}

(In besonder in die Nuwe Testament).

'n Afsonderlike woord vir ,ras" kom naas die verwante begrippe "nasie", „volk", ,geslag", en "taal” in die Bybel nie voor nie. Van hierdie begrippe is nasie die ruimste en mees algemene, sodat 'n nadere bepaaldheid van die aard van die saamhorigheid hierin ten enemale ontbreek. Daarom word dit in die O. en N. Test. so dikwels gebruik vir he'dene. Dit kan ook ons begrip,,ras"insluit (bv. Hand. 17:26). Deur die ander verwante begrippe word die saamhorigheid dan nader beskryf as 'n historiese en politieke (,volk"), as 'n stamverwantskap (,geslag"), as 'n taalkundige (,tale”) en 'n territoriale (,lande”, Gen. 10:31). ${ }^{1}$ ) In wat volg gaan dit nie om die spesifieke rasbegrip nie, maar om al hierdie natuurlike verwantskappe soos hulle ook telkens in verbinding met mekaar voorkom (Dan. 3:4; Openb. 5:9; 7:9; 11:9; 13:7; 14:6; 17: 15) en waarvan ,ras" die omvattendste is. Die metode wat gevolg word sal nie bestaan in die noem en bespreking van enkele los tekste nie. Met los tekste kan enigiets ,uit die Bybel"bewys word. Mens dink al dadelik aan Gal. 3:28: „Daar is nie meer Jood of Griek nie, daar is nie meer slaaf of vryman nie, daar is nie meer man of vrou nie; want julle is almal 
een in Christus Jesus." Andere kan weer wys op Matt. 10:5: „Muenie gaan op die pad na die heidene nie, en moenie ingaan in 'n stad van die Samaritane nie; maar gaan liewer na die verlore skape van die huis van Israel" en meen om by Jesus steun te vind vir die opvatting dat die evangelie teruggehou moet word van die heidene. Jesus verwys selfs, soos gebruiklik by die Jode, na die heidene as „hondjies" wat nie die brood van die kinders moet kry nie (Matt. 15:24). Hiernaas staan natuurlik die uitdruklike sendingbevel, om dissipels te mak van al die nasies (Matt. 28:19). Die geval is dat die uitsprake in historiese verband gesien moet word. Die een woord is uitgespreek tydens Jesus se aardse omwandeling, toe sy optrede streng beperk was tot Israel, terwyl hierdie beperking met sy dood en opstanding en as gevolg van sy verwerping deur Israel weggeval het. By Gal. 3:28 hoef daar slegs aan herinner te word, dat hier ook sprake is van „man" en „vrou”. Dit is dus 'n inlegging van eie gedagtes as hierop 'n beroep gedoen word vir die wegval van die natuurlike grense tussen volke en rasse. Die juiste betekenis van Gal. 3 : 28 is dat, wat ons verlossing in Christus en ons verhouding tot hom betref, dit nie saak maak of mens Jood of Griek, swart of wit is nie, net so min as wat dit saak maak of mens man of vrou is. As van hierdie teks gebruik gemaak word vir die wegval van grense selfs in die kerklike lewe (vgl. slegs 1 Kor. 11 : 21 vv.; $15: 34$ v.) dan geskied dit op onverantwoordelike wyse. Hiermee is meteen die aanduiding gegee van die wyse van ons benadering. In die Skrif kom die openbaring tot ons in historiese vorm en vorm so een geheel. Daarom moet ons die Skrif as geheel laat spreek, hier dan, in soverre dit hierdie vraagstuk raak.

Gaan ons die Skrif na dan blyk dat dit hierdie vraagstuk nie maar terloops raak nie maar dat dit saamgeweef lê met die openbaring van die begin tot die einde. Die lyn loop deur. Dit kan hier slegs in hooftrekke weergegee word.

1. Die Skrif leer dat die hele mensheid uit een bloed ontstaan het. Dit leer die Skeppingsverhaal. Die mensheid is een geslag, of „ras", (Hand. 27:26). Daar bestaan dus nooit die onderskeid tussen mens en mens, hoe verwyderd ook van mekaar, as wat daar bv. bestaan tussen dier- of plantsoorte nie. Hierdie soort vergelykinge om ,apartheid" te verdedig bederf slegs 'n goeie saak. By diere en plante was dit telkens „volgens hulle soorte", om voort te bestaan as verskillende soorte en ook nog as verskillende soorte binne die soorte. By die mensheid bestaan sy eiesoortigheid in teëstelling tot plant en dier en bestaan daarin dat hy geskape is na die beeld van God, almal, en by die mensheid in onder- 
skeiding van die plant en dier was en is daar net eensoortigheid wat wel tot differensiëring moes kom, maar nooit so dat die eenheid daardeur verlore gegaan het nie.

2. Verder het ons ook in die Skrif die geskiedenis van die ontstaan van nasies en rasse, by Babel. Die ontstaan van nasies was die deursetting van 'n oorspronklike skeppingsgedagte teen die poging van mensekant on eenvormigheid en eentaligheid te bewaar (vgl. Deut. 32:8). „Das Einheitsstreben von Gen. 11 ontspringt der menslichen Hybris. Ihr gegenüber stellt Gott durch sein Eingreifen die von ihm gesetzte Ordnung der Völker wieder her. ${ }^{2}$ ). Die Babelse gedagte van uitwissing van grense in een wêreldryk, en 'n eenvormige mensdam gaan dwarsdeur die Skrif tot in Openbaring. Die ryk van die antichris is juis hierdie eenheidsryk waarin die mensheid onder een kroon, as een kultuurgemeenskap verbind word. Dit is die laaste Babel waarvan daar geskrywe staan: „Want God het dit in hulle harte gegee (nl. van die konings van die aarde) om sy bedoeling uit te voer en een bedoeling uit te voer, en hulle heerskappy aan die dier te gee totdat die woorde van God volbring is. En die vrou wat jy gesien het, is die groot stad wat heerskappy voer oor die konings van die aarde," (Openb. $17: 17,18$ ). Volke en nasies het saamgevloei in een watermassa, waarop die vrou sit, 17:1. Dit is die ryk van die antichris, aan wie mag gegee is „oor elke stam en taal en nasie”, 13:7, die teëbeeld van Christus, Matt. 28:18. Hierdie Babel sien ons ongetwyfeld in konstruksie, juis in die strewe, kenmerkend van ons tyd, om alle nasionale en rassegrense uit te wis. Alle strewe om identiteit te bewaar staan gebrandmerk as ,isolasionisme". Hierdie middelpuntsoekende drang staan onder die septer van die atoom, dit is vrees en angs, nie liefde nie. Maar ook op die mure van hierdie Babel-in-konstruksie staan reeds die handskrif „Geval, geval ...", Openb. 18:1. Hierdie Babel sal ook in mekaar stort soos die eerste, en dit sal weer beteken die verlossing van nasies. Die groot menigte voor die troon van God bestaan uit alle nasies en stamme en volke en tale. (Openb. $7: 9$ ). Dit is nie los individue, „persoonlikhede", wat gered word nie, maar die mensheid in al sy geledinge. „Die nasies van die wat gered word" sal wandel in die lig van die stad van God op die nuwe aarde en „die konings van die aarde bring hulle heerlikheid en eer daarin”, Openb. 21:24 en „,hulle sal die eer en die heerlikheid van die nasies daarin bring", 21:26. Die eer en die heerlikheid van die nasies is hulle kultuur. Kultuur is 'n opdrag van God, Gen. $1: 28$, $2: 15$. Elke nasie sal sy eie daarin bring. Die lyn loop deur van die begin tot die einde. 
3. In die middel het ons die uitstorting van die Heilige Gees met die taalwonder, die teëhanger van Babel: Jode en Jodegenote „uit elke nasie wat onder die hemel is" het in hulle „eie taal" oor die groot dade in wie God ,alle dinge wat in die hemele sowel as wat op die aarde is onder een hoof verenig het, Ef. 1:10. Selfs in hierdie eenheid word die van God hoor spreek, Hand. 2:5vv. Dit is dan die eenheid in Christus, onderskeidinge van volkere, tale en nasies nie weggeneem nie. Daar word by die geboorte van die Christelike Kerk nie 'n kerktaal gebore of geëik nie. „Eie tale" kry nog besondere nadruk in die lig van die feit dat daar 'n wêreldtaal was, die Koine, waarin die N. Test. sou geskryf word. Die Heilige Gees maak nie hiervan gebruik nie maar laat die evangelie hoor in die moedertale. Die bedoeling van die Heilige Gees is duidelik, dat die verskeidenheid van tale en daarmee van volke en nasies in die Christelik kerk nie sal wegval nie. Die mening dat die natuurlike verskille in beginsel uitgewis is deur die bloed van Christus en deur die Heilige Gees en dat alleen by die toepassing hiervan in die kerklike lewe rekening gehou moet word met die praktyk, kan nie in ooreenstemming wees met die bedoeling van die Heilige Gees nie. In die lig hiervan kan ook ' $n$ veelrassige kerkgemeenskap alles behalwe „dic ideaal" van die N. Test genoem word. Die beskrywing hiervan is: „a church ... in which, while preserving all racial integreties and relinquishing no part of any racial heritage which the Spirit of God can use, European and African, coloured and Indian, shall achieve such a unity of spirit and purpose ... as only common love and service of a common Lord can create". Dit is blote idealisme wat die samehang tussen godsdiens en kultuur verby sien en, afgesien hiervan, voor die vraag stel van die taal: In watter taal sal die prediking geskied? Die R.K. Kerk het Latyn gekies vir so 'n kerk. Hierdie vreemde taal was egter 'n versperring vir die Woord. Nie in die eenheid van Christus val die verskeidenhede weg nie, maar in die van Babel, die strewe van die mens om hom te verhef bo sy natuurlike beperkinge, ook die van taal en nasionaliteit tot die universeel menslike"). Daar is politieke en kulturele, en ook geestelike en kerklike torings van $\mathrm{Babel}^{5}$ ) waarin die ,aparte en besondese moet opgaan in die universele. 'n Vorm van Christendom en die Kommunisme reik mekaar die hand uit 'n ,geestelike" (idealistiese) en 'n materialistiese hoek. Enerse stemme word gehoor van die V.V.O. en die Wêreldraad van Kerke.

Wat die groot lyne deur die Bybel betref kan vasgestel word, (1) dat God die verskeidenheid gewil het; (2) dat dit „in Christus" wat sy 
koninkryk op aarde kom vestig het en in die Christelike kerk nie wegval nie en (3) alles daarheen wys dat dit in ooreenstemming met die profete, o.a. Jes. $2: 2-4$, Miga $4: 1-3$, Jes. $25: 6 v v$., $51: 4 v$., Sag. 14:16, ens., ook by die wederkoms van Christus sal bly. ${ }^{\circ}$ )

Dit word slegs bevestig as die lyn nader gevolg word deur die Nuwe Testament. Ook hier is dit 'n deurlopende lyn, vanaf die begin.

1. Afstamming is ook in die Nuwe Test. van geen geringe betekenis want dit begin met geslagsregisters. Dit val ook nie „in Christus” weg nie want die geslagsregisters is albei van Christus. Die geslagsregister by Lukas leer aangaande Christus dat hy tot die mensheid behoort nie anders as deur toehorigheid tot ' $n$ bepaalde geslag (Dawid), stam (Juda-, volk (Abraham), ras (Sem). 'n Blote mens-syn bestaan dus ook ,in Christus" nie. Ook hier is die weg nie die van verheffing van die beperkte tot die onbeperkte nie maar die vernedering van die ewige Seun van God om ons „beperkinge" op hom te neem. Ook in sy verheerlikte menslike natuur word hy nog genoem na sy stamnaam (Openb. 5:5, vgl. Hebr. 7:14). Afstamming het ewigheidsbetekenis. Die geslagsregister by Matthéüs sê dat hy die „saad van Abraham” is, in wie ,,al die geslagte van die aarde" en „al die nasies van die aarde" (Gen. 12:3, 22:18) geseën sal word. Dit gaan „in Christus' 'nie maar om individue nie, maar ook om geslagte en nasies.

2. By Johannes die Doper skyn dit inderdaad asof afstamming wegval en nasiegrense uitgewis word: „moenie dink om by julleself te sê: Ons het Abraham as vader nie; want ek sê vir julle dat God mag het om uit hierdie klippe kinders vir Abraham op te wek." Soos uit die laaste gedeelte van die vers blyk, gaan dit hier egter om die vrymag van God. In die kerk is afstamming en volkstoehorigheid nie bepalend nie maar die vrymagtige verkiesing van God, wat egter werk deur die geslagte en die nasies heen. In die gelowiges word die geslagte en die nasies gered. Die ongelowige deel van 'n nasie is sy kaf (Matt. 3:12). Dit is die noue samehang tussen kerk en volk: nie 'n volks-kerk nie; ook nie 'n kerk los van die volk ${ }^{2}$ ) nie, maar so, dat die nasie in werklikheid voortbestaan in die kerk. Hierdie gedagte loop in die N. Test. deur.

3. Jesus het geleer: „Jy moet jou naaste liefhê soos jouself . . ." en het die barmhartige samaritaan voorgehou as 'n voorbeeld van naasteliefde. Hieruit word afgelei: „Die christelikheid is universeel, nie nasionaal nic... Die nasionale kerk het, soos de nasionale staat, die universele begrip vervang. Waarheen lei dit ons? Weg van die Christelikheid 
en die ware humanisme." $)$ Miskien kan hierby nog die woorde van Jesus gevoeg word: „Wie is my moeder? En wie is my broers? . . W Want elkeen wat die wil doen van my Vader wat in die hemele is, die is my broer en suster en moeder" (Matt. 12:48) en ook die van Matt. 10:37. Moet hieruit afgelei word dat Jesus familieliefde veroordeel? Inteëdeel, Hy het familieliefde en die familielewe geheilig (Matt. 15:4, 19:3 - 9, 1315) en daarmee ook volks- en vaderlandsliefde. Slegs twee keer is daar sprake van dat Jesus geween het, een keer by die graf van Lazarus en die ander keer oor Jerusalem (Luk. 19:42, Matt. 23:37). Jesus het sy volk innig liefgehad. „How otherwise can one understand .. the poignancy of the lament over Jerusalem (Matt. 23:37f) and of his forecast of the destruction to come, when he 'beheld the city and wept over it' (Luke 19:41ff). Love of one's country and of one's own people was approved and consecrated by Christ's example". ") En dit nieteenstaande dat 'n verworde nasionalisme een van die oorsake was van sy kruisiging.

Jesus het ook sy optrede beperk tot sy volk, Matt. 15:4, vgl. 10:4. Eers vergader Hy sy volk uit Israel. Eers as hy deur sy volk verwerp is (hy het sy volk nooit verwerp nie) kom die doopbevel: „Gaan dan heen, maak dissipels van al die nasies ..." (Matt. 28:10). Hicruit is weer duidelik: Die verbond van God is met ,alle nasies (Gen. 12:3, $22: 18$ ). Sy volk moet uit alle nasies vergader word. In hulle gelowiges word die nasies gered en so die mensheid in sy verskeidenheid. „In Christus" en in sy kerk val die verskeidenheid van nasies nie weg nie. Uit die doopbevel is verder duidelik wat volgens die Nuwe Testament onder ,universalisme" verstaan moet word. Dit is, dat God nie 'n God van een nasie is nie maar van ,alle nasies". Geen nasie kan aanspraak maak op uitsluitende of besondere bevoorregting nie. „And this is not because he does not care for any of them, but precisely because he cares for them all. Each one, in Christ, is a people for God's own possession, and all of them equally are objects of his love". ${ }^{10}$ )

In hierdie lig moet die gebod van die naasteliefde en die gelykenis van die Barmhartige Samaritaan gesien word. Dit beteken nie gelykskakeling nie; dat die Jood nie meer Jood en die Samaritaan nie meer Samaritaan moet wees nie, maar dat die Jode en Samaritane (al was hierdie Samaritane ook 'n gemengde volk), mekaar moet liefhê as gelyke voorwerpe van God se liefde in Christus. Dit sluit liefde tot die eie nie uit nie („soos jouself”). Liefde is ook veelsoortig: familieliefde, volksliefde, ens. Daarom sluit die een die ander nie uit nie, ewemin as wat 
die een die ander beperk. „Soos jouself" beteken nie gelykstelling (op een vlak bring) deur die ontwikkelingspeil uit te wis nie, hetsy na bo, deur die meen primitiewe op gelyke voet te plaas met gelyke regte (en pligte!) en voorregte (en verantwoordelikhede!) nie, hetsy na onder deur afklimming, soos Rousseau geleer en van der Kemp gedoen het nie. „Soos jouself" beteken ook nie enerse kulture nie, deur die eie af te dwing op 'n ander of die eie weg te werp vir die van 'n ander nie. Dit is nie liefde vir die naaste (soos dit sig dikwels aanbied) nie, maar òf tirannie, òf minagting van die eie. Wat die gebod van die naasteliefde en die gelykenis van die Barmhartige Samaritaan wel inhou, ook ten opsigte van die verhouding van nasies en rasse onderling, is dat die een die ander nie sal verdruk of oorheers of ook sal minag nie, al is hulle eenvoudiger en swakker. Dit geld die groot nasies ten opsigte van die kleinere en ook die hoër ontwikkelde ten opsigte van die minder ontwikkelde, want almal staan gelyk voor God, en hy neem dit juis op vir die kleine en swakke (Matt. 18:7, 19:13vv.). Die Skrif en veral die Nuwe Testament bly egter nie staan by negatiewe nie. En daarom handel ons in ooreenstemming met die gelykenis en vervul ons die gebod eers in die bevordering van die lewe, lewensomstandighede en -geleenthede van die ander en deur opheffing van die minder bevoorregte, soms met dwang, egter nooit met krenking van selfrespek nie. Dit alles word deur Jesus positief saamgevat in die goue reël: „Alles wat julle dan wil hê dat die mense aan julle moet doen - net so moet julle aan hulle ook doen, want dit is die Wet en die Profete" (Matt. 7:12). Dit is die goue reël nie alleen vir pensoonlike verhoudinge nie, maar ook vir die verhouding van rasse en nasies teenoor mekaar. Dit kan alleen in Christus volbring word. Daarom is daar behoud vir die nasies alleen in Christus.

4. Die handhawing van tale by die uitstorting van die Heilige Gees waarmee Handelinge begin lê geheel in 'n lyn met die sendingopdrag van Matt. 28:19, wat ,alle nasies" omvat. 'n Nuwe openbaring is hier dat Israel, wat die Christus tot die uiterste verwerp het, ook nog onder „die nasies" getel mag word en dat die doop met die vergiffenis van sondes wat dit beseël ook nog vóor hulle geld, juis deur die bloed van Christus wat deur hulle gekruisig nie. Daarvoor beroep Petrus hom op die verbond met hulle (die volk Israel) en hulle kinders (die nageslag), wat ook „almal wat daar. ver is" (die heidense nasies) insluit (Hand. 2:37 -39). Hulle kom selfs weer eerste op grond van die verbond met Abraham (3:6). Dit gaan om die volk lsrael en die nasies (vgl. ook 10:42, 43). Dat dit nie maar gaan om gelowige individue uit 'n nasie nie, 
word met soveel woorde uitgespreek: die ongelowiges „sal uit die volk uitgeroei word" $(3: 23)$. Hierdie lyn loop deur vanaf Johannes die Doper. Die nasie bestaan in sy gelowiges voort.

5. Die apostel Paulus, wat gesê het: .In Christus” is daar nie meer "Jood of Griek ..." nie (Gal. 3:28) en dat die middelmuur van skeiding tussen Jode en heidene afgebreek is (Ef. 2:14), het ook gesê: „Ek sou self kon wens om terwille van my broers, my stamgenote na die vlees, 'n vervloeking te wees, weg van Christus af” (Rom. 9:2) en verder: „Broeders die verlange van my hart en die gebed wat ek tot God vir Israel doen, is vir hulle redding" (10:1). Ook in die heidensending het hy steeds die oog op sy volk: ,as ek tog maar net my eie volk jaloers kan maak en sommige uit hulle kan red." (Rom. 11:14). Daar is by Paulus nie sprake van verheffing bo die nasionale as gevolg van „christelikheid” nie. As Christen gaan sy volksverbondenheid tot die uiterste toe. Hierin staan Paulus in 'n lyn met die profeet Jeremia (vgl. Jer. 9:1vv.). Daar is groot ooreenkoms tussen Paulus en Jeremia, veral ook in hierdie opsig dat hulle in die smart gedeel het van miskendes te wees in hulle volksliefde en juis vervolg is deur diegene wat hulle liefhet. Jeremia wys profeties daarop en Paulus bring agterna die bewys, dat volksliefde ,in Christus" nie wegval nie en dat dit juis die Christen is wat sy volk liefhet, soos Christus sy eie volk liefgehad het tot die uiterste toe. Die inhoud van die veelbesproke hoofstukke, Rom. 9-11 kom op die volgende neer: Die volk Israel sal gered word; die verbond van God met hulle (en in hulle met die nasies) kan nie verval nie, daarvoor sorg die Here self; as die "volheid van die nasies", d.i. die uitverkorenes uit alle nasies, ingegaan het, dan sal die "volheid van Israel" gered word, d.i. die volle getal van hulle uitverkorenes (Rom. 11:25, vgl. v. 12). Ook in die ,geestelike Israel" val die onderskeidinge nie weg nie (Gal. 6:16). ${ }^{11}$ ) Die volk Israel sal saam met die nasies sy plek inneem in die volk van God: Israel in sy gelowiges sowel as die nasies in hulle gelowiges. In hierdie lig moet die universele uitsprake van Paulus gesien word. Die afbreek van die muur van afskeiding (Ef. 2:14), beteken nie dat die verskil tussen nasies in Christus wegval nie, maar dat dit by God nie net om Israel gaan nie maar om al die nasies. Die universalisme by Paulus is dieselfde as by Christus soos uitgespreek in die sendingbevel (Matt. 28:19). "Nie Jood of Griek . . nie" (Gal. 3:28) beteken nie dat Jood en Griek hulle identiteit ,in Christus" verloor nie; dat die Jood nie meer ${ }^{12}$ ) Jood en die Griek nie meer Griek is nie, maar dat dit slegs ankom op geloof onverskillig of iemand Jood of Griek, slaaf of vryman, man of 
vrou is. Dit neem nie weg nie dat dit Jode en Grieke . . . is wat tot die geloof kom en dat dit die nasies en die geslagte is, wat in hulle gelowiges gered word. Hierdie lyn van Johannes die Doper loop ook by Paulus deur. Dit word deur Paulus ook nog uitdruklik uitgespreek: „Want hulle is nie almal Israel wat uit Israel is nie". Daarom kan hy ook verklaar dat die verbond met Israel nie verval het nie (Rom. 9:6). In sy gelowiges is Israel gered. ${ }^{13}$ ) So ook die nasies.

„Kerk” kom by Paulus in tweërlei sin voor: (1) in universele sin, die liggaam van Christus, waarvan al die gelowiges lede is en waarop bogenoemde universele uitsprake betrekking het en (2) in plaaslike sin. Die kerk is universeel: Dit gaan oor die nasionale grense (so is die middelmuur van afskeiding ook afgebreek) maar veeg dit nie uit nie. Daar kom „kerke" op die verskillende plekke in die verskillende lande: 'n „Kerk” in Korinthe, 'n „kerk” in Rome, ens., en „kerke” in Galásië, in Macedónië ens. Die kerk gaan na die nasies toe. So kom die Een Kerk in sy veelvormigheid tot openbaring onder die nasies (Ef. 3:9, 10). Weliswaar lees ons nie van aparte kerke van Jode en heidene nie. Die gemeente van Antiochië het bestaan uit Jode en Grieke. Daar was dan ook een wêreldryk met een taal en een kultuur. Dit alies neem nie weg nie: dic rigting van die kerk was na dic nasies toe, na hulle lande in hulle tale. Die beweging is van die middelpunt af na de omtrek, tot aan die uiterste van die aarde, van land tot land (Hand. 1:8) en nie omgekeerd van die omtrek na die middelpunt, 'n samestroming van volke en nasies, rasse en tale na een lokaliteit om daar „saam te aanbid" nie (vgl. Joh. 4:21-23), of 'n samevatting van die baie kerke in 'n sentrale organisasie nie. Die eerste is die geval met die Mohammedanisme met sy pelgrimstogte, iets wat aan die Christendom vreemd is wat die aarde betref, vgl. Hebr. 11:9-16. Die sentrale organisasie is die geval met die Rooms Katolis:sme, wat alle rasse, tale ens. in sigbare organisasie omvat, en ook bedevaarte nie uitsluit nie. Of die Wêreldraad van Kerke so 'n sentrale organisasie wil wees, word nie gesê nie. Wat sy geskiedenis betref moet die antwoord egter bevestigend wees. In ieder geval word „apartheid” ook van hierdie kant skerp veroordeel. Aan die ander kant moet die eenheid van die kerk tot uitdrukking kom, en wel so, dat die besondere ,kerke" met mekaar in verband tree en lewe, ook oor die nasionale en rassegrense heen, nie om weer een kerk te vorm nie - dit kan nie -, want die Kerk is in Christus een. Daar is ook nie aparte nasionale of rasse-kerke nie. So 'n nasionale of rasse-kerkbegrip ken die N. Test. nie. Daar is maar een Kerk, die Liggaam van Christus wat 
tot openbaring kon in baie (plaaslike) kerke onder blankes en gekleurdes, onder al die nasies en met mekaar in verband tree in engere of in ruimere mate na dat die afstand (in watter sin dan ook) groter of kleiner is, "a unity of fellowship which transcends differences without obliterating them" ") soos in die geval van 'n veelrassige gemeenskap, van gesamel'ke aanbidding of gemeenskaplike nagmaalsviering. Dit is almal vorme van „deurbraak”. ${ }^{5}$ ) In hierdie geval is dit geisoleerde individue uit verskillende rasse en volke wat saamkom, terwyl in die kerkverband rasse en volke mekaar ontmoet, wel in die kerklike lewe, maar tog kom ook die nuwe verhouding in Christus tussen die rasse en volke daarin self aan die lig. In die N. Test. word dit o.a. gesien in die Christelike handreiking, 'n beoefening van die gemeenskap van die heiliges (Gal. 2:9--10) oor de grense heen. Dat ,heidene" aan Jode gee, in ruil vir geestelike rykdomme wat hulle ontvang het (Rom. 15:26, 27), meer nog, dat Jode gewillig was om uit die hande van heidene te ontvang (Rom. 15:16, 31) was iets nuuts. Dit is die liefde wat die geske denheid oorbrug maar die verskeidenheid laat bly. Dit kon, en kan, alleen in Christus (2 Kor. $9: 12-15)$.

Die lyn van die Nuwe Testament is reeds deurgetrek tot in Openbaring Alles saamgevat leer die Skrif en in besonder die N. Testament insake rasseverhoudinge: Die eenheid van die menslike geslag, bestem om te ontplooi in ryke verskeidenheid, die eenheid word deur die sonde verwoes, die verskeidenhede omgesit in teëstellinge; dit word deur Christus herstel in die verloste en herskape mensheid, waarin die teëstellinge versoen word, sodat volke en rasse in Christus in 'n nuwe verhouding tot mekaar te staan kom, hierdie verhouding weer saamgevat in die goue reël, Matt. 7:12, wat alleen in Christus verwesenlik kan word, in beginsel hier en ewig hierna, Openb. 22:2. Hierteenoor: Die eenheidsstruktuur van Babel, waarin alles gedoen word om die verskille ook tussen volke en rasse uit te wis en die verlossing gesoek word in die oplossing van geskille nie alleen nie, maar ook van alle verskille in 'n uniforme mensdom.

Die Nuwe Testament leer egter nie alleen dat daar nie uitwissing van grens is nie, maar ook dat God self die grense handhaaf: „Hy het uit een bloed al die nasies van die mensdom gemaak om oor die hele aarde te woon, terwyl Hy vooraf bepaalde tye en die grense van hulle woonplek vasgestel het..." (Hand. 17:26). God self sorg daarvoor dat die verskeidenhede bly, gedurigdeur ook teen die voortdurende eenheidsstrewe van die mensdom in. Hy doen dit op velerlei wyse, o.a. deur verskil in gelaatsuitdrukking, kleur, geestesinstelling, maar veral (1) deur 
taalverskille, "the diversities of languages is a perpetual reminder to proud men that their most perfect temples of spirit are touched by finiteness. ${ }^{10}$ ) . . Rationalizing is always impatient with these barriers of language and of the irrationality of their divergencies" "1) en (2) deur territoriale grense: Volke word, ook in die Bybel, steeds na hulle lande genoem (Gen. 10:31, Neh. 9:10). Op die laaste val die nadruk in Hand. 17:26. Dit beteken sekerlik nie dat daar geen volksverhuisings of nuwe grensreëlinge mag plaasvind nie; ook nie dat daar geen vermenging van nasies en kulture mag wees waardeur nuwe differensiasies (volkere, kulture, tale) gebore word nie, vgl. Jes. 66:8. By sulke vermenginge moet egter allerlei in ag geneem word. Daar is gevalle waarin die Woord van God vermenging uitdruklik verbied. Daar is die apartsetting van Israel in die O. Test., duidelik uitgespreek in Esra 9:12 en Neh. 13:25. Hierby moet weer in ag geneem word dat dit nie gaan om "suiwerheid van bloed" (ras) nie maar om die suiwerheid van die openbaring (Esra 9:11). Israel $m o g$ dan ook vreemde elemente opneem in die volksgemeenskap, en wel, meer die verwyderde (Egiptenare; Deut. 23:8) spoediger as die meer verwante (Moabiete en Ammoniete; Deut. 23:3). Dit geld rasseverhoudinge alleen in soverre dit saamval met die godsdienstige, waar die Christendom bedreig sou word deur vermenging. Die enigste ander verbod op vermenging is op grond van te nabye verwantskap (Deut. 18:6vv.). Nêrens in die Skrif is daar 'n verbod op grond van te groot verwyderdheid nie. Dit gaan hier egter nie alleen om uitdruklike voorskrif nie maar ook om wat gepas of nie gepas is nie. God het vir Adam 'n vrou gemaak as "'n hulp . . . wat by hom pas" (Gen. 2:18). By die eerste huwelik deur Self bevestig word hiermee 'n grondbeginsel neergelê, wat in ag geneem moet word by elke huwelik. Die voorwaarcle vir goeie vermenging is dan tog weer waar daar die nodige verwantskap bestaan, geestelik en kultureel, anders is die vermenging nic gepas nie maar afkeurenswaardig, des te meer na mate die afstand groter is. Die mees gepaste is dan dat 'n volk gebou sal word uit eie geledere. Wat die kulturele betref kan die verskil bestaan in peil en in soort. Waar die twee saamval is vermenging mins gepas. Dit geld kultuur in die algemeen: "It is in the interests of humanity as a whole the the highest type of culture should maintain itself at the highest level of efficiency in order to render the highest service to religion and morality, to thought and art, to scientific and material progress". ${ }^{18}$ ) In hierdie geval moet eintlik gespreek word van 'n gebod omdat kultuur 'n opdrag is van God. Die minste wat gesê kan word is dat dit 'n kultuurvolk nie pas om te vermeng met 'n 
meer primitiewe ras nie, nie alleen terwille van die meer ontwikkelde nie maar ook van die minder ontwikkelde. Hierdie kulturele beperking is egter relatief in die opsig dat die afstand mettertyd kan en moet afneem sowel wat die peil as die andersoortigheid betref tussen volke (rasse) wat gedurig met mekaar in aanraking is. Origens is dit nie moontlik nie om 'n lyn te trek op grond van Skrfgegewens tot waar daar nog en vanwaar daar nie meer vermenging mag wees nie. Daar is nie 'n twee- of driesoortige mensheid nie, maar 'n veelsoortige in allerlei skakering, almal egter "uit een bloed". Die voortplanting van die menslike geslag word in die Woord van God nie beperk, by wyse van voorskrif, binne sekere volks- of rassegroepe nie. „Apartheid" moet egter nie (soos gewoonlik) net gesien word van hierdie negatiewe kant nie. Dit het sy positiewe aspek, ook in hierdie opsig: As 'n volk afgesien van bostaande oorwegings nie bereid is om te vermeng nie en sy so-syn prys te gee nie, dan het hy daarmee God aan sy sy, wat die verskeidenheid van nasies wil. Dit doen alles af. Meer nog, hy moet in die getuienis van sy geskiedenis en tradisie, in sy gevoel en wil, hierin beluister die wil van God wat deur hom gehoorsaam en deur ander nasies gerespekteer moet word. Die veragting hiervan is ewe-cens 'n vergryp teen ,fundamentele menseregte". Dit gaan hier om 'n saak wat nie te beredeneer is nie. Die mensheid het nie die reg om die "tye van nasies" te bepaal nie, net God alleen.

Wat wel geleer word in Hand. 17:26 is dat 'n „multiraçial society" nie die ideaal is van die Nuwe Testament nie maar dat dit volgens die Nuwe Testament iets abnormaals is. 'n Multiracial society word in onderskeiding van 'n „mixed society" as volg omskrywe: „Various communities, differing from one another in culture, religion, race or language (which) live within a single political framework ... The ideal is of friendly communities, living in the same country side by side, with race tension lessened or if possible, eliminated, but without actual racial fusion". ") Hierdie menslike idee of ideaal is onrealisties. Integrasie langs die gehele linie behalwe op een punt (rasvermenging) bestaan maar net in die gedagte. „With race tension lessened . . ." ewe-eens. Die politieke arena sal 'n toneel wees van gedurige ononderbroke rassestryd. Skeiding langs die gehele linie behalwe op kerklike gebied hou ewemin rekening met die werklikheid omdat geestelike in sosiale gemeenskap nie aparte kompartemente is nie. Integrasie tot op 'n sekere punt is nie moontlik nie, al bestaan dit net in samewoning in een land, selfs in aparte groepsgebiede, in dieselfde staatsverband. Een vaderland dra die syne daartoe by om, hoe kort of hoe lang dit mag duur en watter teen. 
maatreëls ook geneem mag word, hetsy deur uitwissing of deur fusie, vreedsaam of deur stryd, geleidelik een volk te maak van die wat saam daarin woon, want God het ,die grense van hulle woonplek vasgestel”. Nie die vermenging nie maar die samewoning in een land van verskillende volke en rasse wat verskillende volke en rasse wil bly, is die abormale. Wat die N. Test. in besonder hier (Hand. 17:26) leer is dit: As 'n nasie hom geroepe voel om sy identiteit te bewaar dan moet hy woon binne sy eie grense. Doen hy dit nie dan moet hy gewillig wees om die volle 'mplikasies daarvan te aanvaar. 'n Middeweg is daar nie.

1) Georg Bertram, in: Thelogisches Wörterbuch zum Neuen Testament, s.v. "ethnos".

2) Idem, pag. 364 , waar verder gesê word: " . . so erscheint auch Dt. 32,8 die Teilung der Welt unter die Völker als göttliche Ordnung, nicht aber als Strafe für menschliche Sünde".

3) Rev. E. W. Grant, in: The Christian Citizen in a Multi-racial Society, a Report of the Rosettenville Conference, July 1949, pag. 12.

4) Vgl. Reinold Niebuhr, Beyond Tragedy, 1944, pag. 28.

5) Idem, pag. 28 e.v.

6) Vgl. Th. WB. pag. 365 .

7) Soos sektes en allerlei internasionale Christelike bewegings, wat wortel in die revival bewegings van die $19 \mathrm{de}$ eeu (hier te lande nie onbekend nie in die vorm van die metodisme). "These movements broke through national and denominational frontiers and created a sense of solidarity between believers, independently of national and denominational connections". Dr. Karlström, aangehaal deur David Hedegárd, Ecumenism and the Bible, 1954, pag. 63. D. Elton Trueblood bepleit ,redemptive societies", vir die redding van die wêreld, „cutting across all existent barriers”, The Predicament of Modern Man, 1944, pag. 104.

8) T. J. Haarhoff, Waarom nie vriende wees nie? pag. 7.

9) Gerald W. Broomfield, The Chosen People or The Bible, Christianity and Race, 1954, pag. 15 .

10) Idem, pag. 16.

11) H. M. Matter, De Toekomst van Israel in het Licht van het Nieuwe Testament, Baarn, 1953, pag. $155 \mathrm{v}$.

12) Die woordjie "meer" ontbreek in die oorspronklike, en bevorder die misverstand met hierdie vers.

13) Idem, pag. 157.

14) Broomfield, a.w. pag. 33, wat egter met hierdie mooi beskrywing blykbaar 'n veelrassige gemeenskap in die oog het.

15) Die twintigste eeu kan genoem word die Ekumeniese Eeu, maar ewegoed as die Eeu van Dcurbraak op kerklike gebied en ook op die terrein van 
die volkerewêreld. In hierdie betekenis word „ekumenies" teenwoordig meesal verstaan.

16) R. Niebuhr, a.w., pag. 39.

17) Idem, pag. 45.

18) Prof. J. du Plessis, aangehaal in: The Christian in a Multi-racial Society, pag. 60, vgl. pag. 106.

19) John Gunther, Inside Africa, 1955, pag. 333.

W. J. SNYMAN. 